\title{
Review of \\ Emergency Diesel Generator Rocker Arm Capscrews
}

March 1985

Prepared for

the U.S. Nuclear Regulatory Commission

Division of Licensing

Office of Nuclear Reactor Regulation

under Contract DE-AC06-76RLO 1830

NRC FIN B2952

Pacific Northwest Laboratory

Operated for the U.S. Department of Energy

by Battelle Memorial Institute 


\title{
DISCLAIMER
}

This report was prepared as an account of work sponsored by an agency of the United States Government. Neither the United States Government nor any agency thereof, nor any of their employees, makes any warranty, express or implied, or assumes any legal liability or responsibility for the accuracy, completeness, or usefulness of any information, apparatus, product, or process disclosed, or represents that its use would not infringe privately owned rights. Reference herein to any specific commercial product, process, or service by trade name, trademark, manufacturer, or otherwise, does not necessarily constitute or imply its endorsement, recommendation, or favoring by the United States Government or any agency thereof. The views and opinions of authors expressed herein do not necessarily state or reflect those of the United States Government or any agency thereof.

\author{
PACIFIC NORTHWEST LABORATORY \\ operated by \\ BATTELLE \\ for the \\ UNITED STATES DEPARTMENT OF ENERGY \\ under Contract DE-AC06-76RLO 1830
}


Technical Evaluation Report

REVIEW OF

EMERGENCY DIESEL GENERATOR

ROCKER ARM CAPSCREWS

March 1985

\author{
Prepared for \\ the U.S. Nuclear Regulatory Commission \\ Division of Licensing \\ Office of Nuclear Reactor Regulation \\ under Contract DE-AC06-76RLO 1830 \\ NRC FIN B2952 \\ Project Title: Assessment of Diesel Engine
Reliability/Operability \\ NRC Lead Engineer: C. H. Berlinger \\ Pacific Northwest Laboratory \\ Richland, Washington 99352
}




\section{FOREWORD}

This report is supplied as part of the Technical Assistance Project, Assessment of Diesel Engine Reliability/0perability, being conducted for the U.S. Nuclear Regulatory Commission, Office of Nuclear Reactor Regulation, Division of Licensing, by the Pacific Northwest Laboratory. The U.S. Nuclear Regulatory Commission funded this work under authorization B\&R 20-19-40-42-1 FIN No. B2952. 


\section{PACIFIC NORTHWEST LABORATORY}

PROJECT APPROVALS

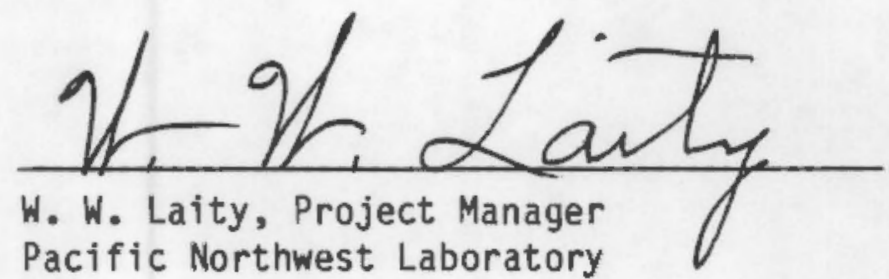

Srophen

W. D. Richmond, Chairman

Senior Review Panel

Pacific Northwest Laboratory
Date March 25,1985 


\section{ACKNOWLEDGMENTS}

This report was compiled by PNL project team members F. R. Zaloudek, R. E. Dodge, and M. Clement based on technical contributions provided by PNL staff members K. I. Johnson and M. C. C. Bampton and PNL consultants S. H. Bush, P. J. Louzecky, and A. Sarsten. 


\section{ABSTRACT}

This report documents Pacific Northwest Laboratory's (PNL) review of the Transamerica Delaval, Inc. (TDI) Diesel Generator Owners' Group evaluation of the rocker arm capscrews used on TDI emergency diesel generators installed in several nuclear power plants. The Owners' Group evaluation is described in the Stone \& Webster Engineering Corporation report, Emergency Diesel Generator Rocker Arm Capscrew Stress Analysis (March 1984), and in two supplements.

Stone \& Webster performed stress analyses on the original "straight section" capscrew design and a new necked-down design used by TOI to secure the rocker arm assembly to the cylinder head structure. On the basis of the stress analyses, Stone \& Webster concluded that both the original and the necked-down designs are adequate for the intended service.

The Stone \& Webster document and other information supplied in response to specific questions were reviewed by PNL and its consultants. PNL concluded that the Stone \& Webster analysis tended to produce nonconservative predictions of dynamic stresses in the capscrews. After considering the capscrew's operational history and estimating the amount of nonconservatism associated with Stone \& Webster's calculations, PNL concludes that both designs are satisfactory. 


\section{CONTENTS}

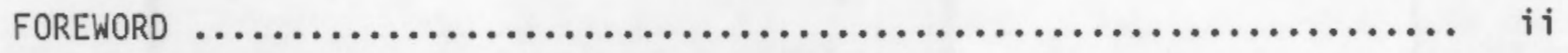

PACIFIC NORTHWEST LABORATORY PROJECT APPROVALS $\ldots \ldots \ldots \ldots \ldots \ldots \ldots \ldots \ldots \ldots$ ii

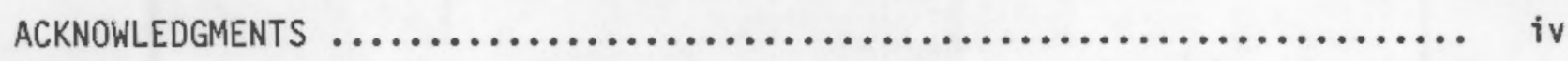

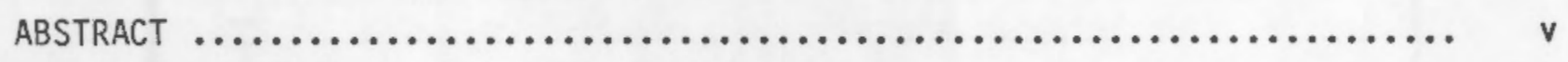

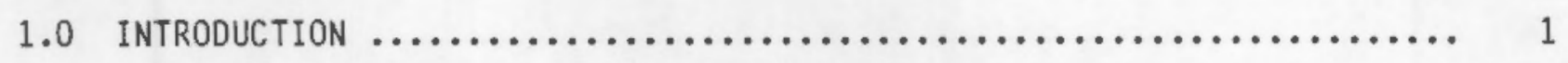

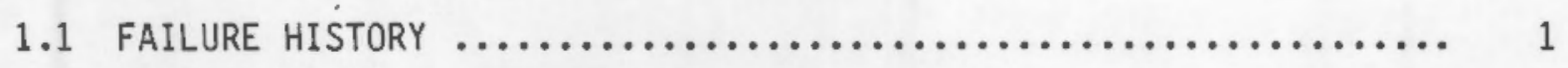

1.2 COMPONENT DESIGN DESCRIPTION $\ldots \ldots \ldots \ldots \ldots \ldots \ldots \ldots \ldots \ldots \ldots \ldots \ldots \ldots \ldots \ldots \ldots \ldots \ldots \ldots$

2.0 OWNERS' GROUP RESOLUTION OF PROBLEM $\ldots \ldots \ldots \ldots \ldots \ldots \ldots \ldots \ldots \ldots \ldots \ldots \ldots$

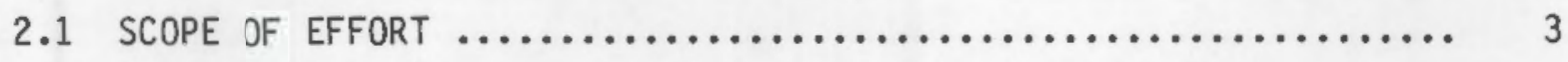

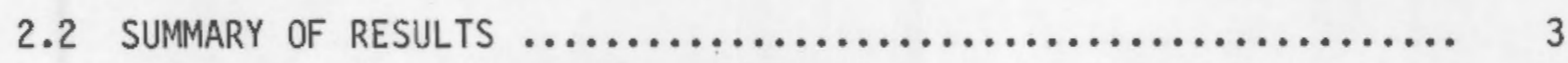

2.3 CONCLUSIONS AND RECOMMENDATIONS $\ldots \ldots \ldots \ldots \ldots \ldots \ldots \ldots \ldots \ldots \ldots \ldots$

3.0 PNL'S EVALUATION $\ldots \ldots \ldots \ldots \ldots \ldots \ldots \ldots \ldots \ldots \ldots \ldots \ldots \ldots \ldots \ldots \ldots \ldots \ldots \ldots \ldots \ldots$

4.0 CONCLUSIONS AND RECOMMENDATIONS $\ldots \ldots \ldots \ldots \ldots \ldots \ldots \ldots \ldots \ldots \ldots \ldots \ldots \ldots \ldots \ldots \ldots \ldots \ldots \ldots$

REFERENCES $\ldots \ldots \ldots \ldots \ldots \ldots \ldots \ldots \ldots \ldots \ldots \ldots \ldots \ldots \ldots \ldots \ldots \ldots \ldots \ldots \ldots \ldots \ldots \ldots$ 


\section{REVIEW OF}

EMERGENCY DIESEL GENERATOR ROCKER ARM CAPSCREWS

\subsection{INTRODUCTION}

The Pacific Northwest Laboratory (PNL) is supporting the U.S. Nuclear Regulatory Commission (NRC) staff in addressing questions of the reliability, operability, and quality assurance of Transamerica Delaval, Inc. (TDI) diesel engines used to provide standby power in some nuclear power plants. These questions were raised because of a major failure in one TDI diesel at the Shoreham Nuclear Power Station in August 1983 and other problems encountered with TDI diesels. One of the principal tasks in PNL's effort is to evaluate the resolution by the TDI Owners' Group of known problems with potential generic applicability.

This report documents PNL's evaluation of the Owners' Group analysis of design adequacy of the capscrews securing the rocker arm assemblies to the cylinder heads in all TOI diesel engines in nuclear service. The details of this analysis were described in the Stone \& Webster Engineering Corporation report, Emergency Diesel Generator Rocker Arm Capscrew Stress Analysis (March 1984), in a supplement to the report (April 1984), and in supplementary calculations (June 1984).

\subsection{FAILURE HISTORY}

The Owners' Group reported that only a few isolated capscrew failures have occurred in nuclear standby service diesel engines. TDI concluded that these failures were the result of insufficient preload.

\subsection{COMPONENT DESIGN DESCRIPTION}

The rocker arm capscrews secure the rocker arm assembly to the cylinder head and transmit the camshaft follower acceleration loads, valve spring loads, and residual cylinder pressure forces from the rocker arm shaft to the cylinder heads. Two capscrew designs have been used. The original design is shown in Figure 1; a newer, modified design is shown in Figure 2 . When installed, the 


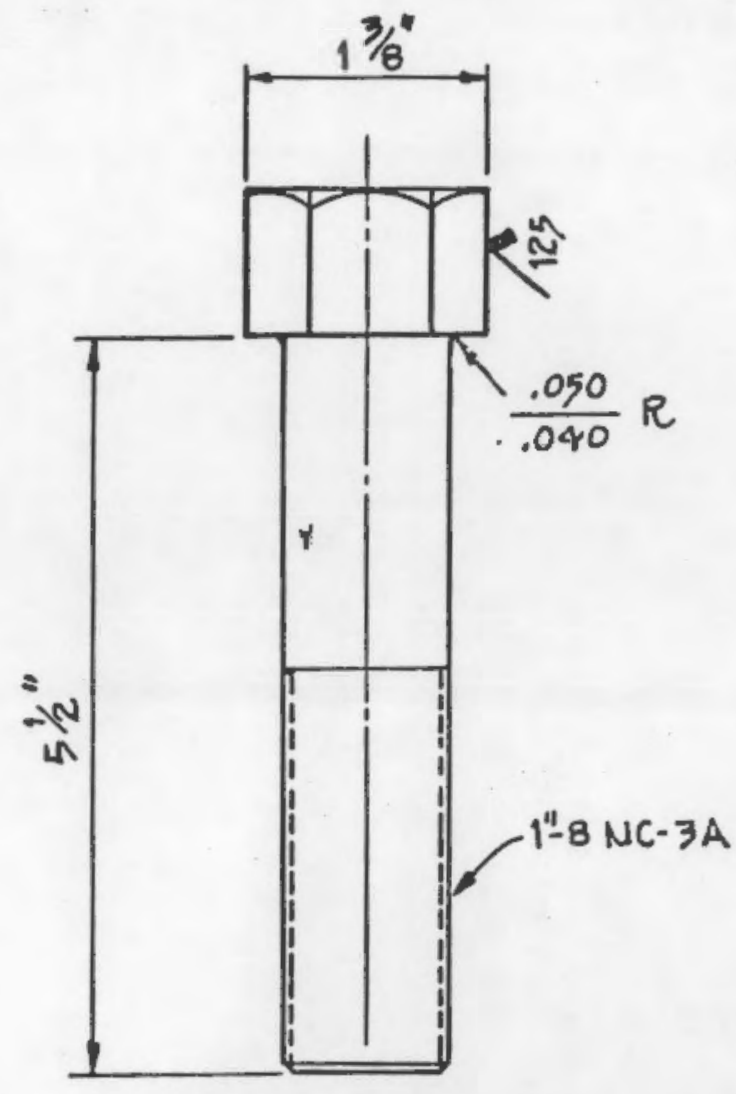

FIGURE 1. Rocker Arm Capscrew Original Design

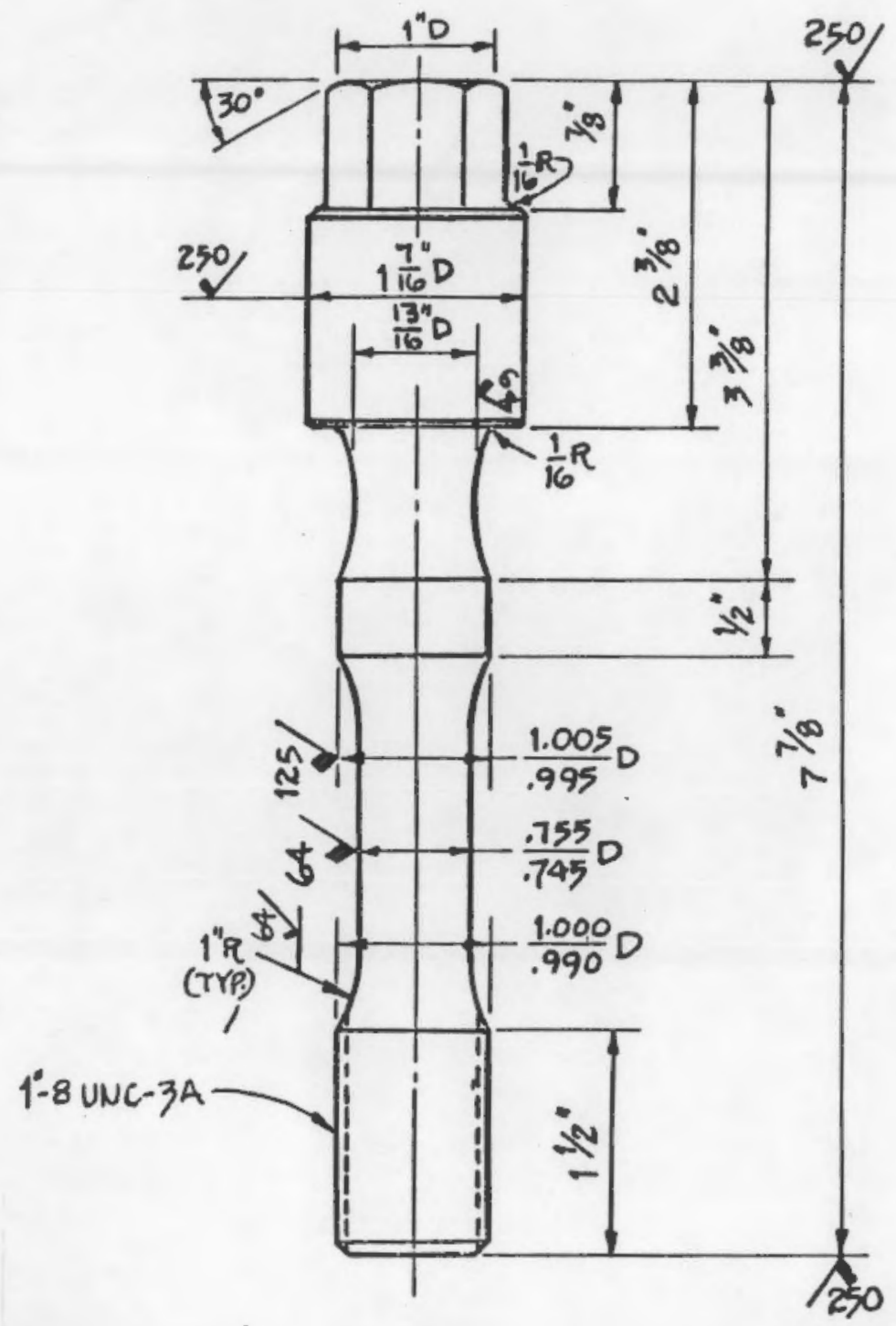

FIGURE 2. Rocker Arm Capscrew Modified Design

Source: Stone \& Webster Engineering Corporation (March 1984) 
rocker arm capscrews are preloaded to a specified torque, resulting in a clamping force on the rocker arm.

\subsection{OWNERS' GROUP RESOLUTION OF PROBLEM}

The adequacy of the design of the rocker arm capscrews was addressed by Stone \& Webster Engineering Corporation, a consultant to the Owners' Group. The objective of the Stone \& Webster effort was to evaluate the ability of both capscrew designs to withstand the necessary preload and oscillatory loads without fatigue cracking, unacceptable preload relaxation, or thread distortion.

\subsection{SCOPE OF EFFORT}

The scope of Stone \& Webster's investigation encompassed four primary activities:

- Evaluate the stresses at the minimum cross-sectional area resulting from capscrew preloads, cam follower acceleration loads, valve spring loads, and residual cylinder pressure forces.

- Compare the total resultant stress to yield and endurance limits for the capscrew.

- Evaluate the thread specification for resistance to distortion and creep.

- Compare the material used in the rocker arm capscrews to the ASTM A-193 Grade B-7 industry standard.

\subsection{SUMMARY OF RESULTS}

Stone \& Webster calculated total applied mean stresses of $41.0 \mathrm{ksi}$ and $50.8 \mathrm{ksi}$ at the minimum cross-sectional area of the original and modified design capscrews, respectively. Cyclic stresses were $0.5 \mathrm{ksi}$ and $0.6 \mathrm{ksi}$, respectively. The yield stress of rocker arm material, AISI 4140 hardened, is $105 \mathrm{ksi}$. The endurance stress is $8.76 \mathrm{ksi}$ for the old design and $37.6 \mathrm{ksi}$ for the modified design. The higher endurance strength for the modified design 
resulted from locating the minimum area in a region of the capscrew free from significant stress concentration factors. Because the total applied mean stress is considerably below the yield point for the material, and because the endurance strength exceeds the cyclic stress by a large margin, Stone \& Webster concluded that both capscrew designs are fatigue-resistant.

Because the capscrews are in a relatively cool region of the engine, Stone \& Webster concluded that creep and stress relaxation would not be a problem. Furthermore, because the yield stress of the material is not exceeded, thread distortion would not occur for the expected service conditions and installation procedures.

\subsection{CONCLUSIONS AND RECOMMENDATIONS}

Based on their analyses, Stone \& Webster concluded that both original and modified capscrew designs are adequate for the intended service if they are properly preloaded. However, the modified design has more margin for fatigue because of its higher endurance limit. Stone \& Webster al so concluded that the threads used for both the original and modified designs will adequately resist distortion.

\subsection{PNL'S EVALUATION}

The Stone \& Webster design review of the rocker arm capscrews used in TDI engines in nuclear service was evaluated by:

- M. Clement, PNL project team

- S. H. Bush, consultant, Review and Synthesis Associates

- P. J. Louzecky, consultant, Engineered Applications Corporation

- A. Sarsten, consultant, Norwegian Institute of Technology

- K. I. Johnson, PNL staff

- M. C. C. Bampton, PNL staff.

During the initial review, a number of questions were raised. Written answers were obtained from the Owners' Group (Ray June 20, 1984). These 
replies to PNL's questions, along with the Stone \& Webster report and supplements, provided the bases for PNL's final review of the Owners' Group analysis of the rocker arm capscrews.

PNL's evaluation of the Stone \& Webster analyses included a detailed review of the loads on the capscrews and resulting stresses. This review led to the following PNL comments:

- The calculated gas pressure at the exhaust valve opening appears low (78 psi). The pressure used in the force calculation was 100 psi for conservatism. However, based on the experience of PNL's diesel engine consultants, it is still substantially below the 130 - to 140-psi pressure expected in a typical engine.

- The polytropic coefficient during expansion used in the calculation was assumed to be 1.3. A more acceptable value would be 1.25 .

- The pressure behind the valve at opening was not considered. However, neglecting backpressure would have a conservative influence on the results.

- The calculations were based upon a theoretical otto cycle (combustion at constant volume), which employs expansion from a point of maximum pressure at top dead center (TDC). A combined otto-Diesel cycle having expansion from some point after TDC would be more appropriate for a modern diesel engine.

- The cam profile used in the calculations does not reflect modern diesel engine practice, but does appear to be numerically correct.

- The rocker arm ratio seems to have been neglected in the calculation of forces on the intermediate push rod.

- The problem is actually three-dimensional rather than twodimensional. The resultant push rod force is mainly counteracted by the nearest capscrew. Furthermore, the resultant force acts at an angle, creating a moment about the edge of the pivot shaft seating flat, which increases the capscrew load. In the Stone \& Webster 
calculations, the resultant force was split evenly between the two capscrews and converted into a purely vertical force.

In consideration of these factors, PNL recalculated the actual fatigue loads on the capscrews and found them to be approximately 3 times greater than those calculated by Stone \& Webster. However, even with the substantially higher fatigue loads and total applied mean stresses, both the original capscrew (8.7-ksi endurance limit) and the modified design (37.6-ksi endurance 1 imit) show suitable margins to fatigue failure on a Goodman diagram.

Operating experience supports the observation that these capscrew designs are satisfactory. The few reported failures were attributed to inadequate preloads, which, in PNL's opinion, is a reasonable determination of the cause of failure.

\subsection{CONCLUSIONS AND RECOMMENDATIONS}

Based on the evaluation of the Stone \& Webster design analysis document and supplements, PNL concluded that the Stone \& Webster calculations tended to produce nonconservative predictions of dynamic stresses in the rocker arm capscrews. However, PNL estimates that the amount of nonconservatism in these predictions is not sufficient to alter the basic conclusion of the Stone \& Webster report-- that the capscrews of both designs are adequate for their intended service. The operating experience with these capscrews supports the adequacy of the designs, but also emphasizes the need to ensure that the proper preload recommended by TOI is initially established and maintained. If the rocker arm capscrews are installed with the proper preload, they should not require any maintenance/surveillance until they are removed for other reasons. 


\section{REFERENCES}

Ray, C. L., Jr. June 20, 1984 . Owners' Group Letter OGTP-85 to C. Berlinger forwarding answers to questions regarding the rocker arm capscrews raised by PNL.

Stone \& Webster Engineering Corporation. March 1984. Emergency Diesel Generator Rocker Anm Capscrew Stress Analysis. Boston, Massachusetts.

Stone \& Webster Engineering Corporation. June 1984. "Rocker Arm Supplemental Calculation." Calculation 11600.60/245.1-MS." Boston, Massachusetts.

Stone \& Webster Engineering Corporation. April 1984. Supplement to the Emergency Diesel Generator Rocker Arm Capscrew Stress Analysis. Boston, Massachusetts. 
DISTRIBUTION

No. of

Copies

OFFSITE

16 Division of Licensing Office of Nuclear Reactor Regulation

U.S. Nuclear Regulatory Commission Washington, DC 20555

ATTN: C. Berlinger (10)

M. Carrington (2)

D. Corley

F. Miraglia

H. Thompson

M. Williams

12 NRC Plant Project Managers

Division of Licensing

U.S. Nuclear Regulatory Commission

Washington, DC 20555

ATTN: B. Buckley

S. Burwel1

D. Hood

D. Houston

K. Jabbour

T. Kenyon

E. McKenna

M. Miller

S. Miner

C. Stahle

J. Stefano

E. Weinkam

2 U.S. Nuclear Regulatory Commission

Public Document Room

Division of Technical

Information and Document Control

Washington, DC 20555
No. of

Copies

P. Lang, NE-14

U.S. Department of Energy

Office of Nuclear Energy

Washington, DC 20555

ONSITE

DOE Richland Operations Office

H. Ransom/M. Plahuta

Pacific Northwest Laboratory

Consultant

P. Louzecky

5 Senior Review Panel

F. Albaugh

S. Bush

C. Hill

W. Richmond

L. Williams

27 Project Team

J. Al zheimer

A. Currie

D. Dingee

R. Dodge

W. Gintner

W. Laity (20)

J. Nesbitt

F. Zaloudek

Technical Information (5)

Publishing Coordination (2) 